\title{
Comparison of nonsense-mediated mRNA decay efficiency in various murine tissues
}

\author{
Almoutassem B Zetoune ${ }^{1}$, Sandra Fontanière ${ }^{1}$, Delphine Magnin², \\ Olga Anczuków ${ }^{1}$, Monique Buisson ${ }^{1}$, Chang X Zhang ${ }^{1}$ and Sylvie Mazoyer*1
}

Address: ${ }^{1}$ Laboratoire de Génétique Moléculaire, Signalisation et Cancer UMR5201 CNRS, «Equipe Labellisée par la Ligue Nationale contre le Cancer», Université Lyon 1, Université de Lyon, Faculté de Médecine, 8 avenue Rockefeller, 69373 Lyon cedex 08, France and 2 Unité de Prévention et d'Epidémiologie Génétique UMR5558 CNRS, Université Lyon 1, Université de Lyon, Centre Léon Bérard, 28 rue Laënnec, 69378 Lyon cedex 08, France

Email: Almoutassem B Zetoune - moutassem.zetoune@recherche.univ-lyon1.fr; Sandra Fontanière - gasse_sandra@yahoo.fr; Delphine Magnin - delphine.magnin@yahoo.fr; Olga Anczuków - anczukow@cshl.edu; Monique Buisson - monique.buisson@recherche.univlyon1.fr; Chang X Zhang - chang-xian.zhang@recherche.univ-lyon1.fr; Sylvie Mazoyer* - sylvie.mazoyer@recherche.univ-lyon1.fr

* Corresponding author

Published: 5 December 2008

BMC Genetics 2008, 9:83 doi:10.1 I86/I47|-2156-9-83
Received: 9 July 2008

Accepted: 5 December 2008

This article is available from: http://www.biomedcentral.com/I47I-2I56/9/83

(c) 2008 Zetoune et al; licensee BioMed Central Ltd.

This is an Open Access article distributed under the terms of the Creative Commons Attribution License (http://creativecommons.org/licenses/by/2.0), which permits unrestricted use, distribution, and reproduction in any medium, provided the original work is properly cited.

\begin{abstract}
Background: The Nonsense-Mediated mRNA Decay (NMD) pathway detects and degrades mRNAs containing premature termination codons, thereby preventing the accumulation of potentially detrimental truncated proteins. Intertissue variation in the efficiency of this mechanism has been suggested, which could have important implications for the understanding of genotypephenotype correlations in various genetic disorders. However, compelling evidence in favour of this hypothesis is lacking. Here, we have explored this question by measuring the ratio of mutant versus wild-type Men I transcripts in thirteen tissues from mice carrying a heterozygous truncating mutation in the ubiquitously expressed Men I gene.
\end{abstract}

Results: Significant differences were found between two groups of tissues. The first group, which includes testis, ovary, brain and heart, displays a strong decrease of the nonsense transcript (average ratio of $18 \%$ of mutant versus wild-type Men I transcripts, identical to the value measured in murine embryonic fibroblasts). The second group, comprising lung, intestine and thymus, shows much less pronounced NMD (average ratio of $35 \%$ ). Importantly, the extent of degradation by NMD does not correlate with the expression level of eleven genes encoding proteins involved in NMD or with the expression level of the Men I gene.

Conclusion: Mouse models are an attractive option to evaluate the efficiency of NMD in multiple mammalian tissues and organs, given that it is much easier to obtain these from a mouse than from a single individual carrying a germline truncating mutation. In this study, we have uncovered in the thirteen different murine tissues that we examined up to a two-fold difference in NMD efficiency.

\section{Background}

Messenger RNA (mRNA) quality control is essential to assure the fidelity of gene expression. It is achieved through several mechanisms among which NonsenseMediated mRNA Decay (NMD) plays a major role. The NMD pathway detects and degrades mRNAs containing 
premature termination codons (PTCs), thereby preventing the accumulation of potentially harmful truncated proteins [1]. NMD is evolutionary conserved, although the way PTCs are recognized by the surveillance machinery may differ between species. In mammals, PTC recognition depends upon the position of the stop codon within the transcript. The normal stop codon is nearly always located in the last exon [2], so any stop codon located $>50$ nucleotides upstream of the last exon-exon boundary will be considered as premature. Recognition is thought to occur during a pioneering round of translation, and exon-exon boundaries are delimited on the transcript by exon-exon junction complexes (EJCs) deposited during splicing [3].

The NMD pathway has important repercussions on the manifestation of human genetic diseases. Although truncating mutations, i.e. mutations that introduce a PTC in the coding sequence, are usually not expected to lead to substantial amounts of truncated proteins, there are situations where the mutant transcripts escape NMD. This happens when the PTC is located in the last exon $[4,5]$, at the beginning of the coding sequence where it can possibly induce translation reinitiation [6-8], or when the PTC is absent from the mutant transcript because of exon skipping [4,9]. Differences in the ability of PTC-containing mRNAs to trigger NMD have been found to explain several phenotype/genotype correlations $[10,11]$. The most striking examples are $\beta$-thalassemia (MIM 141900), which is commonly a recessive disorder, but shows a dominant inheritance pattern when mutations in the $\beta$ globin gene are NMD-incompetent [12], and two different peripheral neuropathies that are both the result of truncating mutations in the SOX10 gene that differ in their ability to trigger NMD [13].

NMD has also long been suspected to influence the clinical outcome of genetic diseases as a result of intertissue variation in the efficiency of this mechanism. Variation in NMD efficiency could lead to the expression of variable amounts of truncated proteins depending on the tissue considered, which might in turn help to explain why truncating mutations in ubiquitously or widely expressed genes appear to affect only a very specific and small subset of tissues in humans. Evidence for variation of NMD efficiency comes from the observation that in patients carrying PTCs in the collagen X gene, low abundance of mutant transcripts was observed in cartilage cells due to NMD, while in lymphoblasts and bone cells, no NMD-mediated mRNA diminution was observed [14].

Here, we have explored the question of variation in NMD efficiency by measuring the relative amount of a PTC-containing Men1 transcript, as compared to the transcript level of the wild-type allele, in 13 tissues taken from het- erozygous Men1 knockout mice. We observed that there is up to a two-fold difference in the efficiency of NMD between the examined tissues.

\section{Results \\ NMD degradation of mutant Men I transcripts in Men I+/4 mice model}

The murine Men1 gene, like its human ortholog, contains 10 exons, of which nine are coding. It has been described that four different Men1 transcripts displaying the same coding sequence are produced through alternative splicing of intron $1[15,16]$. The mouse model we have used in this analysis has been generated by deleting exon 3 in one allele of Men1 [17]. This deletion introduces a PTC in exon 4 of the coding sequence, 164 ter (Figure 1a). Heterozygous Men1 knockout $\left(M e n 1^{+/ \Delta}\right)$ mice of both sexes develop normally and are fertile and healthy until they are at least 7 months of age [17]. Men $1^{+/ \Delta}$ mouse embryonic fibroblasts (MEF) were used to verify that PTC-containing Men1 transcripts were subjected to NMD as expected, given the presence of six exon-exon junctions downstream of the PTC. We found by real time quantitative RT-PCR that mutant transcripts were present at levels of $18 \%$ and $60 \%$ of their wild-type counterpart without and with the NMD inhibitor puromycin, respectively (Figure 1b).

\section{Relative amount of Men I mutant transcripts}

We measured the ratio of mutant versus wild-type Men1 transcripts in 13 different tissues taken from four Men $1^{+/ \Delta}$ mice. The values ranged from $16 \%$ to $36 \%$, as seen on Figure 2. Statistical analysis showed that there was a significant difference between two distinct groups of tissues; one comprised of testis/ovarian, brain and heart (average ratio of $18 \%$ ), and the other of lung, intestine and thymus (average ratio of $35 \%$ ).

The Men1 gene has been reported to be expressed in all the tissues examined, albeit at variable levels, by Northern blot analysis $[16,18,19]$. Quantification by quantitative RT-PCR analysis confirmed this finding. The number of copies was normalized to the amount of Hprt1 and $\beta$-actin transcripts (Figure 3). The lowest level of Men 1 transcripts was found in spleen and stomach while the highest level was found in testis and brain (nearly 4 -fold difference); the differences observed in the other tissues were not statistically significant. No correlation between NMD efficiency and Men1 transcript levels was observed.

\section{Expression levels of the genes involved in NMD}

NMD triggering in humans, based on present models, hinges on the interaction of critical protein components, hUpf2, hUpf3a/hUpf3b, that are bound to the EJC (composed in the cytoplasm of Y14, Magoh, eIF4AIII and hBarentsz) with a molecule, hUpf1, recruited to the posttermination complex deposited at the PTC [3]. The SMG1 
a

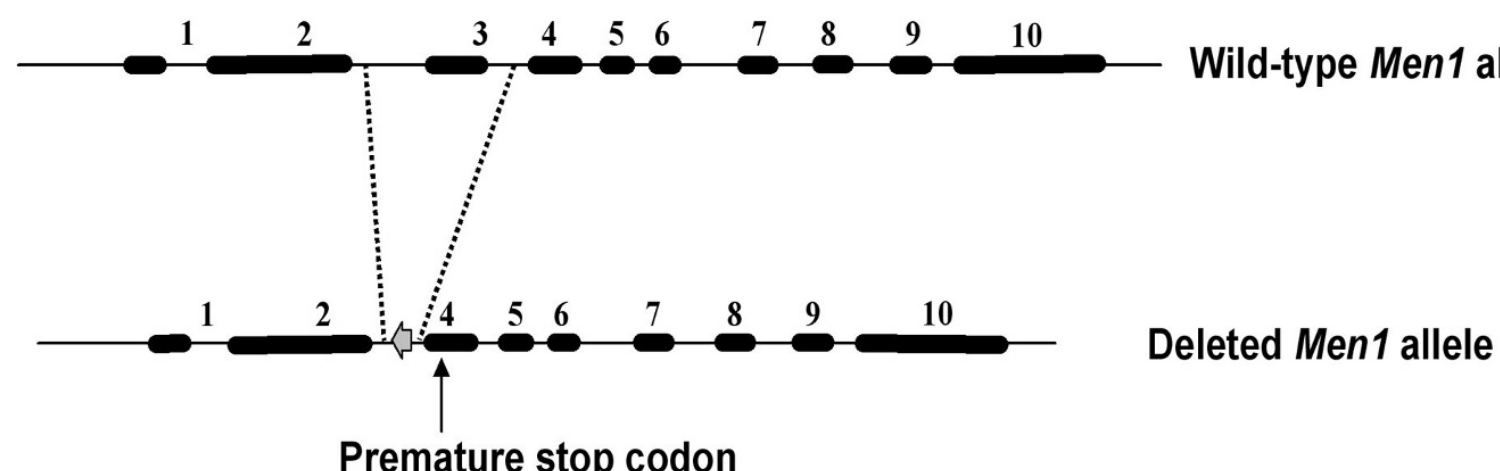

Premature stop codon

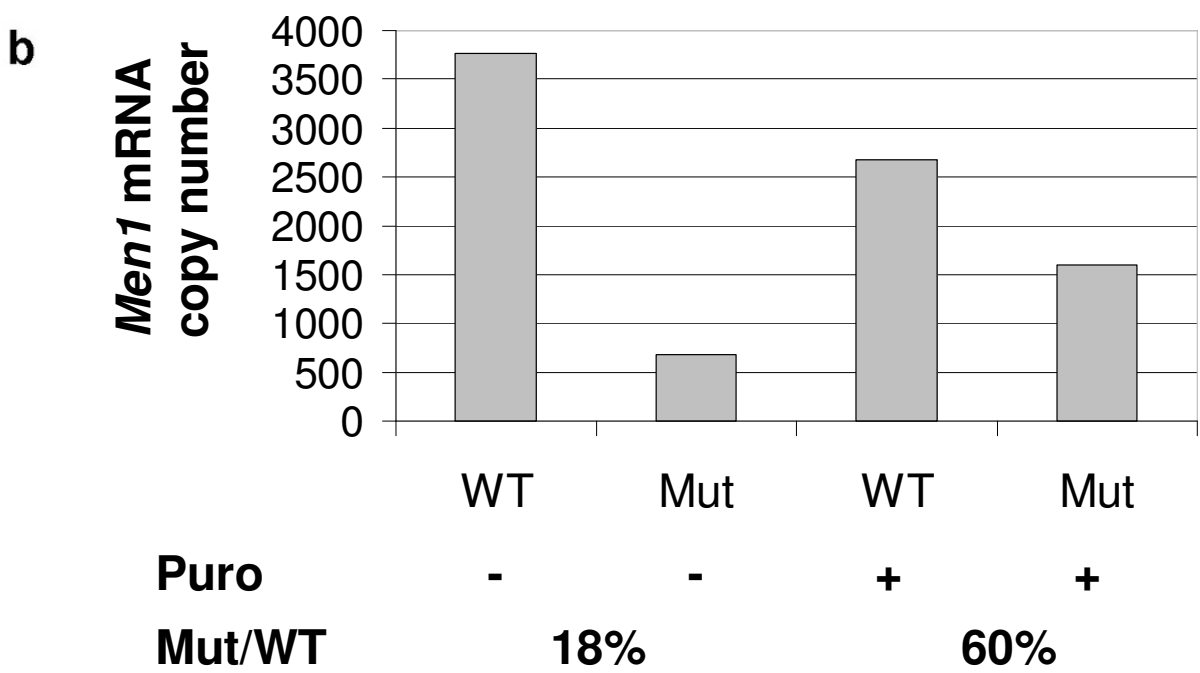

Figure I

Description of the Men I mouse model used in the analysis. (a) Schematic representation of the mutant and of the wildtype allele of the Men I gene in the heterozygous Men I mutant mice. Black boxes and lines represent exons and introns respectively. The grey horizontal arrow depicts a loxP sequence, and the black vertical arrow shows the location of the premature stop codon generated by exon 3 deletion. The strategy used to delete Men I exon 3 in mice has been described previously [I 7]. (b) Transcript copy number were measured by quantitative RT-PCR using $50 \mathrm{pg}$ of RNA extracted from Men ${ }^{+/ \Delta}$ mouse embryonic fibroblasts (MEF) untreated or treated with puromycin (Puro). Specific amplification of either the wild-type (WT) or the mutant $(\mathrm{Mu})$ transcript lacking exon 3 was achieved using the primers described in the Methods section.

kinase, in turn, binds to this complex and phosphorylates hUpf1, which leads to subsequent recruitment of RNA degrading enzymes. The association of these proteins with the post-spliced mRNA is essential as their depletion, mediated by RNA interference, has been shown to suppress degradation of NMD substrates [20,21]. Furthermore, NMD can be recapitulated by tethering the hUpf factors, Magoh, Y14, eIF4AIII, or hBarentsz within the 3'UTR of a reporter mRNA in human cells [22].
Human UPF1 [23], UPF2 [24], MAGOH [25], CASC3 (encoding hBarentsz) [26], and EIF4A3 [27] genes have been shown to be ubiquitously expressed by Northern blot, but their level of expression varies among tissues. In order to more precisely determine the extent of these variations in mice, and to investigate the possibility of an eventual link with NMD efficiency, we have measured the amount of mRNAs transcribed from the genes encoding nine of the proteins involved in NMD by real time quan- 


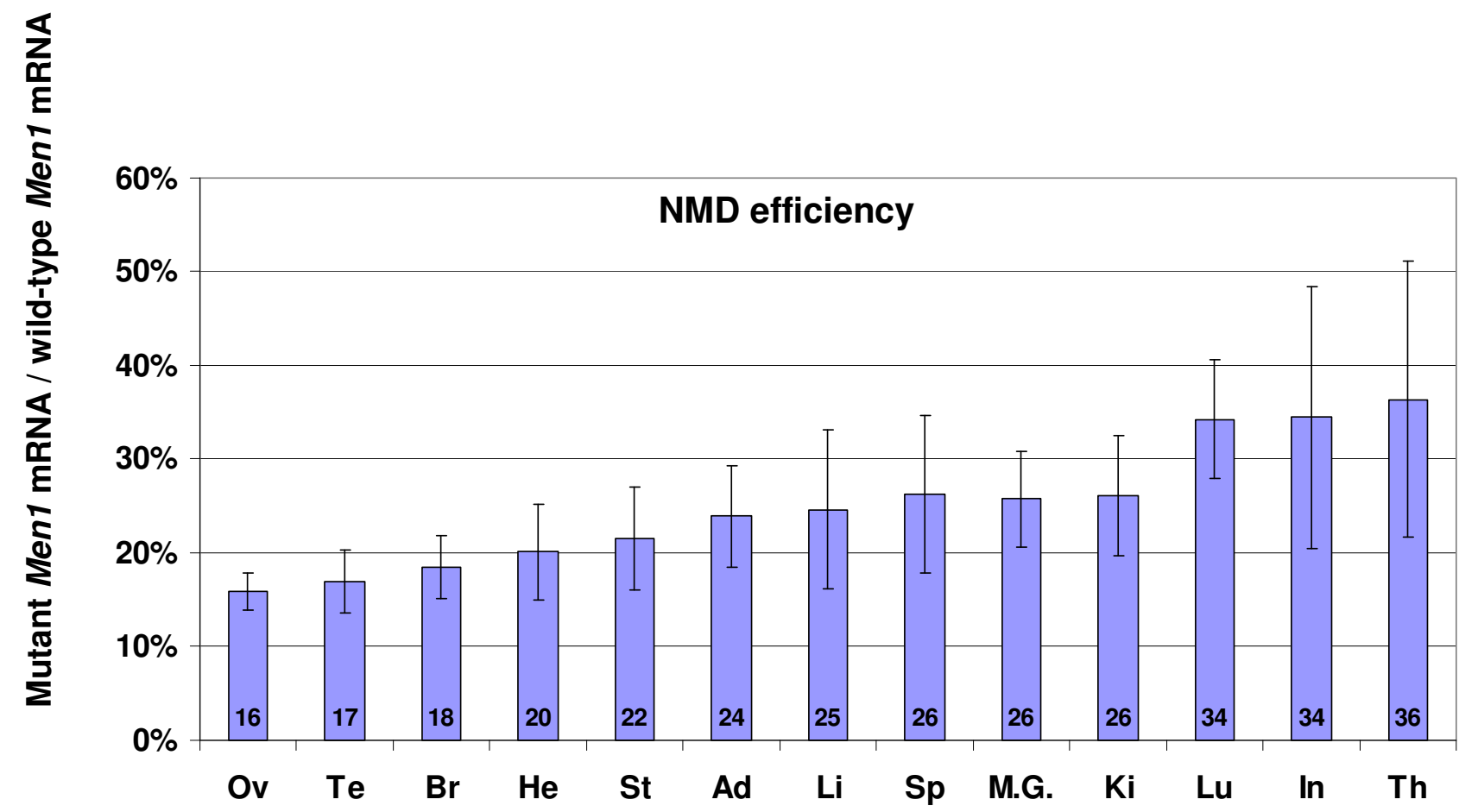

Figure 2

NMD efficiency in I 3 tissues of mice heterozygous for a truncating mutation in the Men I gene. NMD efficiency is expressed as a ratio of the amount of mutant Men I transcripts versus wild-type species, as measured by quantitative RT-PCR. Each bar on the graph represents the mean value of at least 3 independent measurements ( \pm standard deviation) in four samples of the same tissue (two samples only were used for testis and ovary).

titative RT-PCR: Upf1, Upf2, Upf3a, Upf3b, Smg1 (also known as RICKEN), $y 14$ (also known as Rbm8a), Mago, Casc 3 and Eif $4 a 3$ (Figure 4 and 5). We also analysed the level of expression of the genes encoding the splicing coactivators/alternative splicing factors that have been shown to interact with the EJC, SRm160 and RNPS1 (Srrm1 and Rnps1 respectively in mice) (Figure 6), given the described link between efficiency of splicing and efficiency of NMD [28], and given the fact that the abundance of RNPS1 has been reported to determine the variability in efficiency of NMD in three strains of HeLa cells [29]. The same RNA samples were used as previously described for measuring levels of Men 1 transcripts, and the number of copies was likewise normalized to the amount of Hprt1 and $\beta$-actin transcripts. A great variation in the mean level of expression of the eleven studied genes was observed: Mago transcripts (1000 copy per 50 pg of total RNA) are 500 times more abundant than Casc 3 transcripts (2 copies). Included within these boundaries are Rnps1 (275 copies), $y 14$ (265 copies), Upf3a (160 copies), Srrm 1 (130 copies), Eif4a3 (100 copies), Upf3b (90 copies), Upf2 (60 copies), Upf1 (15 copies) and Smg1 (10 copies).
Concerning tissues variations, no statistical difference in the amount of transcripts was seen in the case of Rnps 1 (Figure 6). For $\gamma 14$, testis and heart were significantly different from ovary, brain, stomach, adrenal, spleen, mammary gland, kidney and intestine (Figure 5). Testis, heart and thymus were significantly different from brain, intestine, mammary gland, spleen and stomach for Mago (Figure 5). For the remaining genes, the only tissue showing a significant variation was testis (Figure 4, 5, 6), with an amount of transcripts 4 to 50 times higher than in all the other tissues. No clear correlation could be drawn between the efficiency of NMD and the level of expression of any of the mRNAs encoding proteins essential to this mechanism.

\section{Discussion}

Intertissue variation in NMD efficiency has long been suggested to modulate the clinical outcome of genetic diseases. Indeed, such a variation would mean that in some tissues more than in others, translation of residual mRNAs containing PTCs could potentially lead to func- 


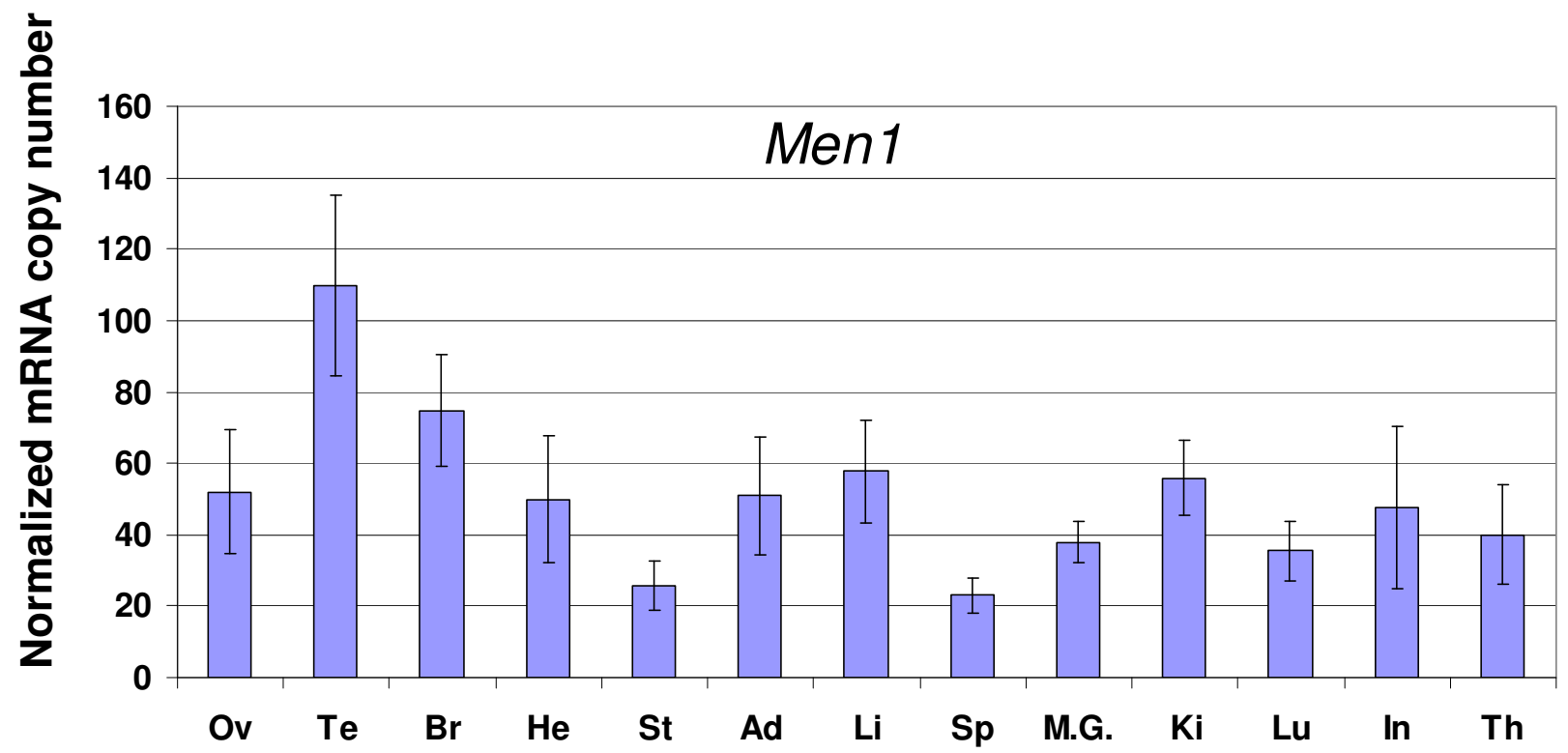

Figure 3

Men I transcript levels in 13 murine tissues. Transcript levels (copy number per 50 pg of RNA extracted from each of the mentioned tissue) were measured by quantitative RT-PCR, and normalized to the level of $H$ prt $I$ and $\beta$-actin transcripts. Each bar on the graph represents the mean value of 3 independent measurements ( \pm standard deviation) in four samples of the same tissue (two samples only were used for testis and ovary).

tionally important expression of truncated proteins and influence the phenotype.

The first hint that NMD efficiency could vary between tissues from the same individual came from the study by Bateman and colleagues on truncating mutations in the collagen X gene, COL10A1, responsible for Schmid metaphyseal chondrodysplasia (MIM 156500) [14]. They showed that NMD completely removed the mutant COL10A1 transcripts in cartilage tissue and cells, but not in non-cartilage cells. However, this COL10A1 study presented two particularities that could restrict the notion of NMD efficiency variation to this gene. Firstly, nonsensemediated reduction in abundance of nonsense COL10A1 mRNAs is not governed by the same parameters as those in the classical process. Indeed, competency for NMD in this case is specified by the 3'UTR and mRNA decay is only triggered by truncating mutations introducing a PTC in a 3 ' region of the terminal exon, which contain more than $90 \%$ of the coding sequence [30]. Secondly, the COL10A1 gene is expressed exclusively in cartilage cells, and therefore, NMD of COL10A1 PTC-containing transcripts in non-cartilage cells (bone cells and lymphoblasts) was assessed on "illegitimate" transcripts, i.e. tissue-specific transcripts found at very low levels in non-expressing cells. A correlation between the amount of transcripts and the extent of degradation by NMD was not observed in the case of the Men1 gene in our study. However, Men1 is ubiquitously expressed and variations of a maximum 5fold were observed amongst the studied tissues. It remains possible that illegitimate COL10A1 transcripts are not translated and that this is the reason why they are not subjected to NMD.

Another related, but distinct matter, concerns interindividual variation in NMD efficiency. Patients carrying identical mutations can show variable reduction of mutant transcript levels in the same cell type [4,31]. In the study of Linde and coll., interindividual variability in NMD efficiency was not only observed in the case of the CFTR transcripts in nasal epithelial cells from patients carrying the W1282X mutation but also in the case of five natural NMD substrates in epithelial cell lines derived from two unrelated patients carrying the same mutations [31]. While intertissue variations of NMD efficiency are probably the result of differences between tissues in the level of expression of the proteins involved in NMD, interindividual variations are likely to be linked to DNA variations in 

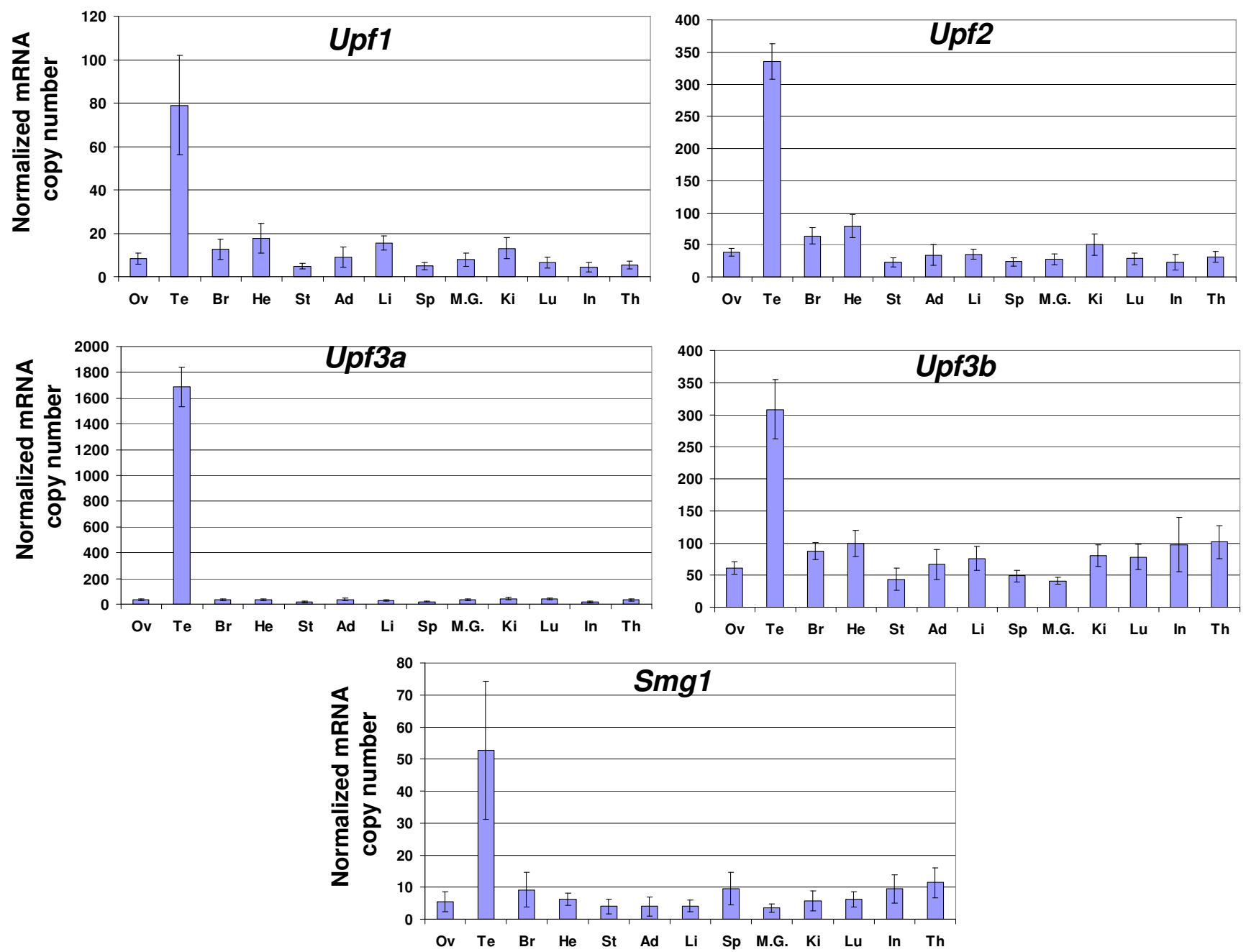

Figure 4

Transcript levels of the UpfI-3 and Smg I genes in I 3 murine tissues. Transcript levels (copy number per 50 pg of RNA extracted from each of the mentioned tissues) were measured by quantitative RT-PCR using the same samples as previously, and normalized to the level of $\mathrm{Hprt}$ and $\beta$-actin transcripts. Each bar on the graph represents the mean value of at least 3 independent measurements ( \pm standard deviation) in four samples of the same tissue (two samples only were used for testis and ovary). Please note that the scale showing the normalized number of transcripts is different for each gene. Ov: ovary; Te: testis; Br: brain; He; heart; St; stomach; Ad: adrenal gland; Li: liver; Sp: spleen; M.G.: mammary gland; Ki: kidney; Lu: lung; In: intestine; Th: thymus.

the human genome within the genes encoding the proteins involved in NMD. These two levels of variations are intermingled when the efficiency by which the same truncating mutation triggers NMD is compared in different tissues of different individuals, as in the study by Resta et al [32], and it is therefore not possible in these situations to estimate the contribution of each phenomenon.

Given the difficulties to obtain different tissues from a single patient, mouse models appeared as an attractive alternative to evaluate the efficiency of NMD in multiple mammalian tissues. Indeed, this question was addressed in a study using the gus ${ }^{m p s}$ mouse, a model of mucopolysaccharidosis type VII (MIM 253220), which harbours a NMD-competent truncating mutation in the ubiquitously expressed $\beta$-glucuronidase gene [24]. However, only homozygous animals were studied, which precluded measurement of steady-state levels of mutant versus wildtype transcripts in different tissues of the same mouse. Their analysis, performed by Northern blot, reported that all eight tissues examined (thymus, spleen, skeletal muscle, liver, kidney, lung, heart and brain) showed efficient degradation of the mutant transcript as it was undetectable in Gus null mutant mice [24], but was not able to 

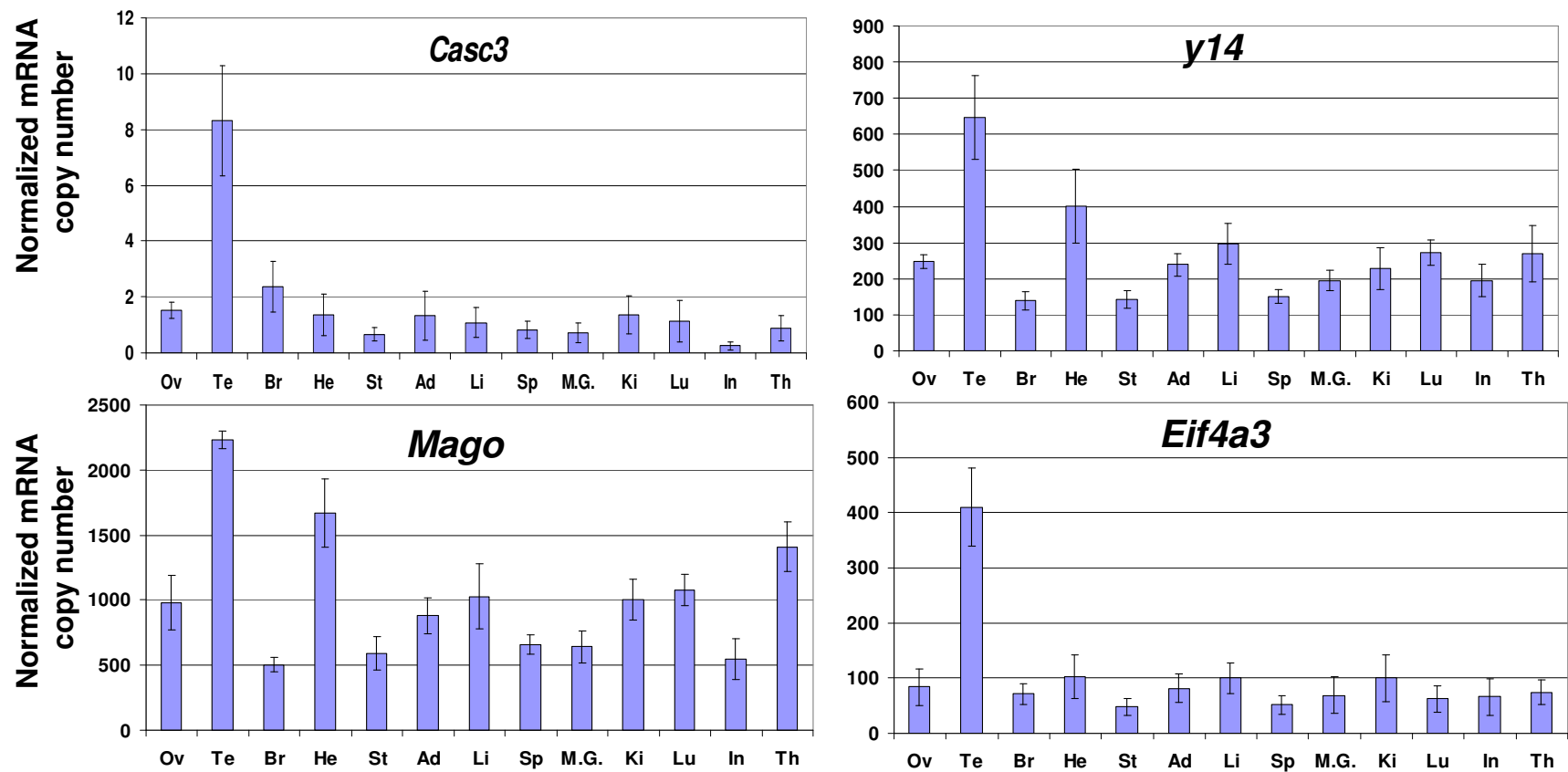

Figure 5

Transcript levels of the genes encoding the EJC core proteins in I 3 murine tissues. Transcript levels (copy number per $50 \mathrm{pg}$ of RNA extracted from each of the mentioned tissues) were measured by quantitative RT-PCR using the same samples as previously, and normalized to the level of $H$ prt l and $\beta$-actin transcripts, as in Figure 4.

uncover discrete variations in NMD efficiency. A recent study performed on a knockin mouse model in which one wild-type Chek2 allele has been replaced by an allele carrying the 1100delC mutation showed that the mutant transcripts undergo NMD in MEFs and in four tissues (brain, heart, kidney and liver), but to varying degrees
[33]. This analysis was performed by quantitative RT-PCR on RNA extracted from tissues taken from wild-type, Chek2 1100delC heterozygous and Chek2 1100delC homozygous animals. The RT-PCR protocol used did not allow the discrimination between the wt and the mutant Chek2 transcript species and therefore, NMD efficiency
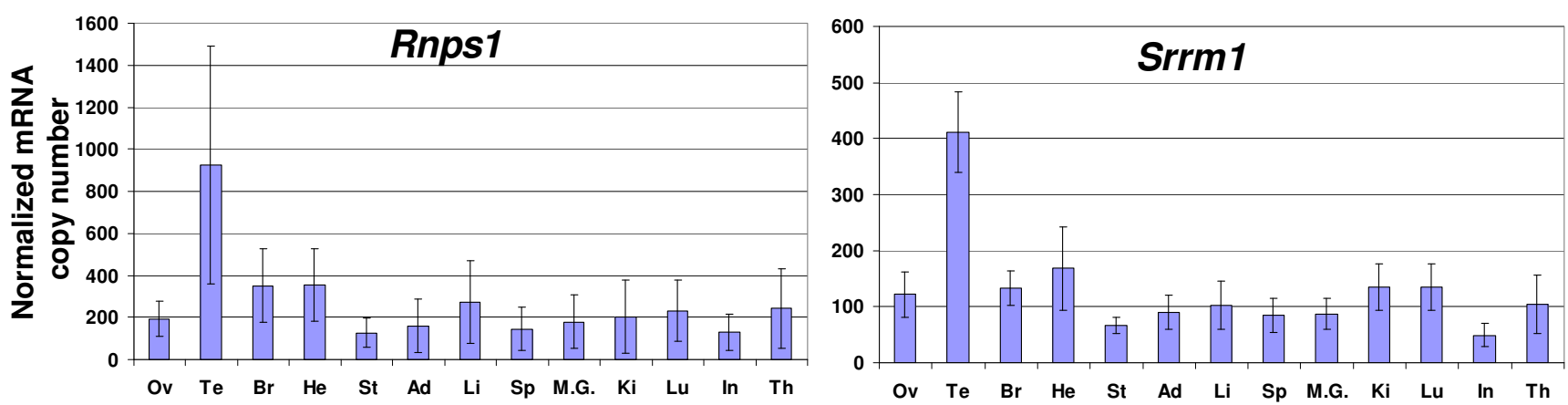

Figure 6

Transcript levels of the genes encoding two splicing factors involved in the NMD mechanism in 13 murine tissues. Transcript levels (copy number per $50 \mathrm{pg}$ of RNA extracted from each of the mentioned tissues) were measured by quantitative RT-PCR using the same samples as previously, and normalized to the level of $\mathrm{Hprt} /$ and $\beta$-actin transcripts, as in Figure 4. 
was expressed as the amount of both transcripts normalized to GAPDH transcripts. Variations were observed, but it couldn't be ruled out that they result from variations in the levels of the GAPDH transcripts, as these have been reported to vary depending on the tissues examined [34].

Here, we have quantified for the first time the extent of variation in NMD efficiency by measuring the ratio of mutant versus wild-type Men1 transcripts in 13 tissues taken from mice heterozygous for a truncating mutation, and have found up to a two-fold difference. The organs most frequently involved clinically in the Men 1 syndrome (the parathyroids, the pituitary and the pancreas) were not all tested in our analysis; furthermore, it has not been possible to verify the expression of a truncated menin protein as all the available antibodies are directed against the C-terminal part of the Menin protein. Therefore, we have not been able to assess whether the differences in NMD efficiency that we have uncovered plays a role in the physiopathology of the disease in the Men $1^{+/ \Delta}$ mice.

Although NMD efficiency varies depending upon the gene, we do not expect that the extent of variation that we have observed is specific to the Men1 gene. However, our results need to be confirmed with other mouse models carrying a heterozygous truncating mutation in ubiquitously-expressed genes. Additionally, it would be interesting to also test physiologic NMD substrates. Unfortunately, several features shared by these physiologic substrates limit their use to disclose intertissue variations of NMD efficiency. Indeed, the examination of the expression profile in human cells depleted of hUpf1 revealed that most upregulated transcripts result from alternative splicing events or from the use of alternative translation start site that introduce upstream open reading frames [35]. Both mechanisms show striking variation across tissue types, and therefore, it would not be possible to attribute variations in PTC+ transcript levels in various tissues to differences in NMD efficiency, as they could also be due to differences in the levels of alternative splicing, or in the use of alternative translation start sites.

NMD efficiency is sometimes calculated as the ratio between the amount of mutant transcripts in the absence and in the presence of a NMD inhibitor (often a translation inhibitor) $[31,32,36]$, which would have the advantage in the present case to bypass the aforementioned problem. However, notwithstanding the fact that it is impossible to inhibit NMD in non-growing cells, it is to be noted that the level of up-regulation upon NMD inhibition is highly variable among NMD-sensitive transcripts and it has never been demonstrated that this level correlates with NMD efficiency. On the contrary, the results we obtained when studying BRCA1/2 transcripts bearing truncating mutations showed that it is not the case [4,37].
It has been shown recently that RNPS1, a protein component of the EJC, could determine the variability of NMD efficiency in three strains of HeLa cells [29]. However, we did not find in our study on Men $1^{+/ \Delta}$ mice a correlation between NMD efficiency in tissues and the level of transcripts encoding RNPS1, no more than with the levels of the other transcripts that we have tested. It remains possible that these transcript levels are not reflective of the amount of proteins present in these tissues.

\section{Conclusion}

The level of intertissue variations that we have found might be lower than expected based on previous results [14]. Nevertheless, if it were to reflect the situation in humans, there may be circumstances where this two-fold difference is sufficient to modify the ultimate phenotype by allowing the expression of twice as many aberrant truncated proteins with potential dominant-negative or gainof-function in particular tissues compared to others. Furthermore, the observed variation means that the stability of nonsense transcripts may significantly differ in the relevant tissues from the stability determined in commonly used cell lines.

\section{Methods \\ Mice, cells and tissues}

Heterozygous mice carrying the deleted Men1 allele $\left(\mathrm{Men} 1^{+/ \Delta}\right)$ are from a mixed $129 / \mathrm{Sv}$ and C57BL/6 background [17]. Mouse embryonic fibroblasts (MEF) were isolated from littermates of E12.5 embryos derived from intercrosses of Men $1^{+/ \Delta}$ mice [17] and immortalized according to $3 \mathrm{~T} 3$ protocol published previously [38]. Tissues (stomach, liver, heart, spleen, lung, mammary gland, kidney, ovary, testis, brain, intestine, thymus and adrenal) were harvested from 4 two month-old Men $1^{+/ \Delta}$ mice (2 male and 2 female), briefly washed in phosphate-buffered saline (PBS), quickly frozen in liquid nitrogen and transferred for long term storage at $-80^{\circ} \mathrm{C}$.

All animal experiments were conducted in accordance with the standards of human animal care and were approved by the International Agency for Research on Cancer's Animal Care and Use Committee.

\section{Cell culture}

MEF cells were maintained in Dulbecco's modified Eagle medium (Invitrogen, Cergy Pontoise, France) supplemented with $10 \%$ foetal calf serum, 100 units $/ \mathrm{ml}$ penicillin, $100 \mu \mathrm{g} / \mathrm{ml}$ streptomycin, $2 \mathrm{mM}$ L-glutamine (VWR, Fontenay sous Bois, France) and $100 \mu \mathrm{M} \beta$-mercaptoethanol in a $5 \% \mathrm{CO} 2$ incubator at $37^{\circ} \mathrm{C}$.

For NMD (translation) inhibition, cells were treated with a fresh puromycin solution (Sigma-Aldrich, St Quentin Fallavier, France) at the final concentration of $100 \mu \mathrm{g} / \mathrm{ml}$ 
of culture for 6 hours and harvested, washed once with PBS, and subsequently used for total RNA isolation.

\section{RNA extraction and reverse transcription}

Frozen tissues were homogenized in liquid nitrogen using a CRYOPIX ${ }^{\circledR}$ grinder (Alphelys, Plaisir, France). Total RNA was isolated from $5 \times 10^{6} \mathrm{MEF}$ cells or from $\sim 30 \mathrm{mg}$ of tissue powder using the NucleoSpin RNA II kit (MachereyNagel, Hoerdt, France), according to the manufacturer's instructions.

RNA concentrations were quantified with a Biophotometer (Eppendorf, Le Pecq, France) and integrity of RNA was checked by $1 \%$ agarose gel electrophoresis. Protein contamination was monitored by A260/A280 ratio. All samples had a ratio between 1.7 and 2 .

A constant amount of 500 ng of total RNA was reverse transcribed in a total volume of $20 \mu \mathrm{l}$ using $20 \mathrm{pmol}$ of oligo(dT) primers (Promega, Charbonnières, France) and 50 units of Expand Reverse Transcriptase (Roche, Meylan, France) according to the manufacturer's instructions. All tissues of each mouse were reverse transcribed at the same time, and all investigated samples have been reverse transcribed using the same batch of oligo(dT) and enzyme.

\section{Real-time PCR}

PCR amplification and analysis were achieved using a LightCycler 2.0 instrument (Roche) and software version 4.0 , respectively (Roche). The specific primers for quantitative real-time PCR were designed using publicly available sequences from the Nucleotide Sequence Database (see Additional file 1). To amplify wild-type Men1 transcripts, we used a forward primer complementary to a sequence localised in exon 3 (absent in the mutant Men 1 transcript species) and a reverse primer complementary to a sequence localised at the exon 3/exon 4 junction. To amplify mutant Men1 transcripts, we used a forward primer complementary to a sequence localised in exon 2 and a reverse primer complementary to a sequence localised at the exon 2/exon 4 junction. The primers designed to amplify the transcripts of the genes encoding NMD factors, splicing factors, or the control genes also span at least one exon-exon junction (except for Upf3b and Hprt1). All primers were synthesized by MWG Biotech AG. Mastermix for each PCR run was prepared in a total volume of 10 $\mu \mathrm{l}$ with 2.5 or $5 \mathrm{mM} \mathrm{MgCl}_{2}$ (see Additional file 2), $0.5 \mu \mathrm{M}$ of each primer, $1 \mu$ l LightCycler Fast Start DNA Master SYBER Green I mix, and $2 \mu \mathrm{l}$ of cDNA. All templates were amplified using the following protocol: after $10 \mathrm{~min}$ of denaturation at $95^{\circ} \mathrm{C}$, samples were subjected to 40 cycles of denaturation for $15 \mathrm{~s}$ at $95^{\circ} \mathrm{C}$, annealing for $5 \mathrm{~s}$ at $64^{\circ} \mathrm{C}$ or $66^{\circ} \mathrm{C}$ (see Additional file 1), and elongation for $10 \mathrm{~s}$ at $72^{\circ} \mathrm{C}$. A melting curve was performed at the end of the 40 cycles by heating the samples at a rate of $0.2^{\circ} \mathrm{C} / \mathrm{s}$ starting at $70^{\circ} \mathrm{C}$ up to $97^{\circ} \mathrm{C}$ with continuous measurement of fluorescence. The specificity of the real time RT-PCR reaction performed to amplify Men1 wild-type or mutant transcript species was controlled using RNA extracted from Men $1^{+/+}$and Men $1^{-/-}$MEF cells.

Each sample was analysed by at least three PCR reactions. Absolute quantification of RNA copy number was determined using a standard curve that is generated with serial dilutions of a PCR product with a known concentration (as measured with the Biophotometer).

\section{NMD efficiency and transcript levels assessment}

NMD efficiency is expressed as the ratio of the number of mutant versus wild-type Men1 RNA copies in each tissue. To assess the level of expression of the 11 genes encoding proteins involved in NMD and of the wild-type Men1 allele, in each of the 13 tissues, the number of RNA copies was normalized with the average number of RNA copies for the Hprt1 and $\beta$-actin genes. Copy numbers of the transcripts of these two genes are shown in Additional file 1.

\section{Statistical analysis}

To test the significance of the differences between tissues, transcript measurements being nested within tissue and tissues being nested within mouse, data were modelled using a hierarchical mixed model [39]. The "tissue" factor was studied as a fixed effect and the "mouse" factor embedded within the "tissue" factor as a random effect in order to take into account the within-mouse correlation. Estimations were done using the maximum likelihood method using the nlme library of the software $\mathrm{R}$ version 2.2.1 [40]. The statistical significance level was 0.05.

\section{Authors' contributions}

ABZ carried out the bench work. SF carried out the dissection of the mice. DM performed the statistical analysis. MB participated in the bench work. CXZ participated in the design and coordination of the study and helped to draft the manuscript. SM conceived of and designed the study, and drafted the manuscript. All authors read and approved the final manuscript.

\section{Additional material}

\section{Additional File 1}

Primers and parameters used for the quantitative RT-PCR analysis. Click here for file

[http://www.biomedcentral.com/content/supplementary/14712156-9-83-S1.pdf] 


\section{Additional File 2}

Transcript levels of the Hprt 1 and $\beta$-actin genes in 13 murine tissues. Click here for file

[http://www.biomedcentral.com/content/supplementary/14712156-9-83-S2.pdf]

\section{Acknowledgements}

We thank MD Ware for carefully reading and correcting the manuscript, OM Sinilnikova and D Cox for helpful discussions. This work was supported by a grant from le Comité Départemental du Rhône de la Ligue contre le Cancer. ABZ was supported by a fellowship from the Damas University (Syria) and from the Fondation pour la Recherche Médicale (FRM), SF by fellowships from the Comité Départemental de la Loire de la Ligue contre le Cancer and from the Association pour la Recherche sur le Cancer, and OA by a fellowship from the Comité Départemental de Saôneet-Loire de la Ligue contre le Cancer.

\section{References}

I. Behm-Ansmant I, Izaurralde E: Quality control of gene expression: a stepwise assembly pathway for the surveillance complex that triggers nonsense-mediated mRNA decay. Genes Dev 2006, 20(4):391-398.

2. Scofield DG, Hong $X$, Lynch M: Position of the Final Intron in Full-Length Transcripts: Determined By NMD? Mol Biol Evol 2007, 24:896-899.

3. Maquat LE: Nonsense-mediated mRNA decay: splicing, translation and mRNP dynamics. Nat Rev Mol Cell Biol 2004, 5(2):89-99.

4. Perrin-Vidoz L, Sinilnikova OM, Stoppa-Lyonnet D, Lenoir GM, Mazoyer S: The nonsense-mediated mRNA decay pathway triggers degradation of most BRCAI mRNAs bearing premature termination codons. Hum Mol Genet 2002, I I(23):2805-28|4.

5. Tournier I, Raux G, Di Fiore F, Marechal I, Leclerc C, Martin C, Wang $\mathrm{Q}$, Buisine MP, Stoppa-Lyonnet D, Olschwang S, et al:: Analysis of the allele-specific expression of the mismatch repair gene MLH I using a simple DHPLC-Based Method. Hum Mutat 2004, 23(4):379-384.

6. Buisson M, Anczukow $O$, Zetoune $A B$, Ware MD, Mazoyer S: The I 85delAG mutation (c.68_69delAG) in the BRCAI gene triggers translation reinitiation at a downstream AUG codon. Hum Mutat 2006, 27( I 0): 1024- 1029.

7. Paulsen M, Lund C, Akram Z, Winther JR, Horn N, Moller LB: Evidence that translation reinitiation leads to a partially functional Menkes protein containing two copper-binding sites. Am J Hum Genet 2006, 79(2):2 I4-229.

8. Puel A, Reichenbach J, Bustamante J, Ku CL, Feinberg J, Doffinger R, Bonnet M, Filipe-Santos O, Beaucoudrey L, Durandy A, et al.: The NEMO mutation creating the most-upstream premature stop codon is hypomorphic because of a reinitiation of translation. Am J Hum Genet 2006, 78(4):691-70I.

9. Disset A, Bourgeois CF, Benmalek N, Claustres M, Stevenin J, TufferyGiraud S: An exon skipping-associated nonsense mutation in the dystrophin gene uncovers a complex interplay between multiple antagonistic splicing elements. Hum Mol Genet 2006 , I5(6):999-1013

10. Holbrook JA, Neu-Yilik G, Hentze MW, Kulozik AE: Nonsensemediated decay approaches the clinic. Nat Genet 2004, 36(8):801-808.

II. Khajavi M, Inoue K, Lupski JR: Nonsense-mediated mRNA decay modulates clinical outcome of genetic disease. Eur J Hum Genet 2006, I4(10): 1074-1081.

12. Hall GW, Thein S: Nonsense codon mutations in the terminal exon of the beta-globin gene are not associated with a reduction in beta-mRNA accumulation: a mechanism for the phenotype of dominant beta-thalassemia. Blood 1994, 83(8):2031-2037.
13. Inoue K, Khajavi M, Ohyama T, Hirabayashi S, Wilson J, Reggin JD, Mancias P, Butler IJ, Wilkinson MF, Wegner M, et al.: Molecular mechanism for distinct neurological phenotypes conveyed by allelic truncating mutations. Nat Genet 2004, 36(4):36 I-369.

14. Bateman JF, Freddi S, Nattrass G, Savarirayan R: Tissue-specific RNA surveillance? Nonsense-mediated mRNA decay causes collagen $X$ haploinsufficiency in Schmid metaphyseal chondrodysplasia cartilage. Hum Mol Genet 2003, I 2(3):2 I 7-225.

15. Forsberg L, Zablewska B, Piehl F, Weber G, Lagercrantz S, Gaudray $P$, Hoog C, Larsson C: Differential expression of multiple alternative spliceforms of the Men I tumor suppressor gene in mouse. Int J Mol Med 200I, 8(6):68I-689.

16. Stewart C, Parente F, Piehl F, Farnebo F, Quincey D, Silins G, Bergman L, Carle GF, Lemmens I, Grimmond S, et al.: Characterization of the mouse Men I gene and its expression during development. Oncogene 1998, I 7( I 9):2485-2493.

17. Bertolino P, Tong WM, Galendo D, Wang ZQ, Zhang CX: Heterozygous Men I mutant mice develop a range of endocrine tumors mimicking multiple endocrine neoplasia type I. Mol Endocrinol 2003, I 7(9): |880-1892.

18. Bassett JH, Rashbass P, Harding B, Forbes SA, Pannett AA, Thakker RV: Studies of the murine homolog of the multiple endocrine neoplasia type I (MENI) gene, men I. J Bone Miner Res 1999, 14(I):3-10.

19. Guru SC, Crabtree JS, Brown KD, Dunn KJ, Manickam P, Prasad NB, Wangsa D, Burns AL, Spiegel AM, Marx SJ, et al.: Isolation, genomic organization, and expression analysis of Men I, the murine homolog of the MENI gene. Mamm Genome 1999, I 0(6):592-596.

20. Ferraiuolo MA, Lee CS, Ler LW, Hsu JL, Costa-Mattioli M, Luo MJ, Reed R, Sonenberg N: A nuclear translation-like factor elF4AIII is recruited to the mRNA during splicing and functions in nonsense-mediated decay. Proc Nat Acad Sci USA 2004, I0I(I2):41 I8-4123.

2I. Mendell JT, ap Rhys CM, Dietz HC: Separable roles for rentI/ hUpfl in altered splicing and decay of nonsense transcripts. Science 2002, 298(5592):419-422.

22. Gehring NH, Kunz JB, Neu-Yilik G, Breit S, Viegas MH, Hentze MW, Kulozik AE: Exon-junction complex components specify distinct routes of nonsense-mediated mRNA decay with differential cofactor requirements. Mol Cell 2005, 20(I):65-75.

23. Perlick HA, Medghalchi SM, Spencer FA, Kendzior RJ Jr, Dietz HC Mammalian orthologues of a yeast regulator of nonsense transcript stability. Proc Natl Acad Sci USA 1996, 93(20): 10928-10932.

24. Mendell JT, Medghalchi SM, Lake RG, Noensie EN, Dietz HC: Novel Upf2p orthologues suggest a functional link between translation initiation and nonsense surveillance complexes. Mol Cell Biol 2000, 20(23):8944-8957.

25. Zhao XF, Colaizzo-Anas T, Nowak NJ, Shows TB, Elliott RW, Aplan PD: The mammalian homologue of mago nashi encodes a serum-inducible protein. Genomics 1998, 47(2):319-322.

26. Macchi P, Kroening S, Palacios IM, Baldassa S, Grunewald B, Ambrosino C, Goetze B, Lupas A, St Johnston D, Kiebler M: Barentsz, a new component of the Staufen-containing ribonucleoprotein particles in mammalian cells, interacts with Staufen in an RNA-dependent manner. J Neurosci 2003, 23( I 3):5778-5788.

27. Li Q, Imataka H, Morino S, Rogers GW Jr, Richter-Cook NJ, Merrick WC, Sonenberg N: Eukaryotic translation initiation factor 4AIII (eIF4AIII) is functionally distinct from eIF4AI and elF4AII. Mol Cell Biol I999, I 9(I I):7336-7346.

28. Gudikote JP, Imam JS, Garcia RF, Wilkinson MF: RNA splicing promotes translation and RNA surveillance. Nat Struct Mol Biol 2005, I 2(9):801-809.

29. Viegas MH, Gehring NH, Breit S, Hentze MW, Kulozik AE: The abundance of RNPS I, a protein component of the exon junction complex, can determine the variability in efficiency of the Nonsense Mediated Decay pathway. Nucleic Acids Res 2007, 35( I 3):4542-455I.

30. Tan JT, Kremer F, Freddi S, Bell KM, Baker NL, Lamande SR, Bateman $J F$ : Competency for nonsense-mediated reduction in collagen $X$ mRNA is specified by the $3^{\prime}$ UTR and corresponds to the position of mutations in Schmid metaphyseal chondrodysplasia. Am J Hum Genet 2008, 82(3):786-793.

31. Linde L, Boelz S, Nissim-Rafinia M, Oren YS, Wilschanski M, Yaacov Y, Virgilis D, Neu-Yilik G, Kulozik AE, Kerem E, et al.: Nonsense- 
mediated mRNA decay affects nonsense transcript levels and governs response of cystic fibrosis patients to gentamicin. J Clin Invest 2007.

32. Resta N, Susca FC, Di Giacomo MC, Stella A, Bukvic N, Bagnulo R, Simone C, Guanti G: A homozygous frameshift mutation in the ESCO2 gene: evidence of intertissue and interindividual variation in Nmd efficiency. J Cell Physiol 2006, 209(I):67-73.

33. Bahassi el M, Penner CG, Robbins SB, Tichy E, Feliciano E, Yin M, Liang L, Deng L, Tischfield JA, Stambrook PJ: The breast cancer susceptibility allele CHEK2*II00delC promotes genomic instability in a knock-in mouse model. Mutat Res 2007, 6 16(I2):20I-209.

34. Barber RD, Harmer DW, Coleman RA, Clark BJ: GAPDH as a housekeeping gene: analysis of GAPDH mRNA expression in a panel of 72 human tissues. Physiol Genomics 2005, $21(3): 389-395$.

35. Mendell JT, Sharifi NA, Meyers JL, Martinez-Murillo F, Dietz HC: Nonsense surveillance regulates expression of diverse classes of mammalian transcripts and mutes genomic noise. Nat Genet 2004, 36(1 0): 1073-1078.

36. Linde L, Boelz S, Neu-Yilik G, Kulozik AE, Kerem B: The efficiency of nonsense-mediated mRNA decay is an inherent character and varies among different cells. Eur J Hum Genet 2007, I5(II): I I56-I I62.

37. Ware MD, DeSilva D, Sinilnikova OM, Stoppa-Lyonnet D, Tavtigian SV, Mazoyer S: Does nonsense-mediated mRNA decay explain the ovarian cancer cluster region of the BRCA2 gene? Oncogene 2006, 25(2):323-328.

38. Wang ZQ, Auer B, Stingl L, Berghammer H, Haidacher D, Schweiger M, Wagner EF: Mice lacking ADPRT and poly(ADP-ribosyl)ation develop normally but are susceptible to skin disease. Genes Dev 1995, 9(5):509-520.

39. Sullivan LM, Dukes KA, Losina E: Tutorial in biostatistics. An introduction to hierarchical linear modelling. Stat Med 1999, I 8(7):855-888.

40. R: A Language and Environment for Statistical Computing. Vienna, Austria; 2004
Publish with Bio Med Central and every scientist can read your work free of charge

"BioMed Central will be the most significant development for disseminating the results of biomedical research in our lifetime. "

Sir Paul Nurse, Cancer Research UK

Your research papers will be:

- available free of charge to the entire biomedical community

- peer reviewed and published immediately upon acceptance

- cited in PubMed and archived on PubMed Central

- yours - you keep the copyright 